\title{
ANALISIS KEMAMPUAN MENULIS KARANGAN DESKRIPSI DALAM BAHASA INDONESIA MELALUI MEDIA GAMBAR SERI PADA SISWA KELAS VII SMP N 18 LAU KABUPATEN MAROS
}

\author{
Naki ${ }^{1}$. Nurhayati ${ }^{2}$, Abidin $^{3}$ \\ 1,2,3 Program Studi Bahasa Indonesia, Fakultas Ilmu Budaya, Universitas Hasanuddin \\ naki19@yahoo.com \\ nurhayatisyair@gmail.com
}

\begin{abstract}
This study aims, namely (1) describes the ability to write essay description of the class VII SMP Negeri 18 Lau through the use of media image series and (2) to analyze the obstacles faced by students of class VII SMP Negeri 18 Lau in arranging a bouquet of descriptions using the media picture series. This research is a qualitative research. This research data in the form of bouquets description seventh grade students of SMP Negeri 18 Lau. Data collection methods are methods refer to Technical note. Data were analyzed with descriptive methods. The results showed that the analysis of the ability to write essay description of the class VII SMP Negeri 18 Lau through the use of media image series shows (1) the ability to organize ideas in an integrated manner, (2) choice of words / diction precise, (3) the use of vocabulary in varied, (4) the creation of cohesion and coherence and (5) writing techniques in accordance with Indonesian enhanced spelling (EYD). The constraints in the use of media such images in learning, from the point of view of teachers that (a) some teachers still use traditional learning methods, (b) the limited ability of teachers to provide media images in accordance with the concept of learning and (c) the teacher has not been able to use media image series of continuous learning. As from the student's perspective (a) The student has not mastered the rules of spelling properly, (b) students are less serious about work and (c) the influence of the local language diversity.
\end{abstract}

Keywords: student, description, image series

\section{PENDAHULUAN}

Keterampilan menulis merupakan salah satu dari keempat komponen keterampilan berbahasa Indonesia yang memiliki peranan penting dalam kehidupan manusia. Dengan menulis, seseorang dapat mengungkapkan pikiran dan gagasan untuk mencapai maksud dan tujuan. karangan deskripsi adalah karangan yang melukiskan sesuatu sesuai dengan keadaan sebenarnya, sehingga pembaca dapat mencitrai (melihat, mendengar, dan mencium) apa yang dilukiskan sesuai dengan keadaan sebenarnya sehingga pembaca dapat mencitrai (melihat, mendengar, merasakan, dan mencium) apa yang dilukiskan sesuai dengan citra penulisnya.Keterampilan menyusun teks deskripsi secara tertulis adalah keterampilan untuk membuat tulisan yang berhubungan dengan suatu objek yang berbentuk deskripsi. Keterampilan menulis deskripsi memang menjadi satu keterampilan berbahasa yang paling sulit untuk dikuasai. Hal ini disebabkan adanya dua unsur yang harus dikuasai oleh penulis, yaitu unsur bahasa, seperti ejaan, struktur kalimat, kohesi, dan koherensi. Adapun unsur nonbahasa yang dijadikan ide atau gagasan dalam sebuah tulisan, meliputi pengetahuan dan pangalaman penulis. 
Media pembelajaran diartikan segala sesuatu yang dapat digunakan untuk menyalurkan pesan atau isi pelajaran, merangsang pikiran, perasaan, perhatian, dan kemampuan siswa sehingga dapat mendorong proses belajar mengajar. Media gambar seri adalah urutan gambar yang mengikuti suatu percakapan dalam hal memperkenalkan atau menyajikan arti yang terdapat pada gambar. Dikatakan gambar seri karena gambar satu dengan gambar lainnya memiliki hubungan keruntutan peristiwa. Asalan digunakannya media gambar seri adalah agar media gambar tersebut dapat membantu menyajikan suatu kejadian peristiwa yang kronologis dengan menghadirkan orang, benda, dan latar. Kronologi atau urutan kejadian peristiwa dapat memudahkan siswa untuk menuangkan idenya dalam kegiatan bercerita.

Gambar seri juga merupakan komponen dari media gambar sebagai alat bantu penyampaian materi pelajaran dan membantu mempercepat pemahaman atau pengertian pada siswa sesuai dengan tujuan yang ingin dicapai, kondisi dan keterbatasan yang ada mengingat kemampuan dan sifat - sifat khasnya (karekteristik) media yang bersangkutan.

Berdasarkan hasil observasi awal yang dilakukan di SMP Negeri 18 Lau kelas VII melalui pemberian tugas menulis karangan deskripsi, terlihat bahwa siswa masih mengalami kesulitan dalam pembelajaran menulis karangan deskripsi. Hal ini dapat dilihat dari karangan deskripsi siswa di bawah ini.

Contoh (1)

Ada pemandangan yang sangat indah dan membuat salah satu seorang terkesan dengan sekolahku ini yaitu aku. Suasana sekolahku ini sangat sejuk dan enak untuk dipandang. Dimana pohong-pohong yang rindang yang membuat udara sejuk. Bangunan yang baru saja direnovasi membuat pandangan mata menjadi enak.
Contoh (1) di atas adalah petikan karangan deskripsi siswa kelas VII. Pada contoh tersebut, terdapat ketidaksesuaian penggunaan panca indera dalam mendeskripsikan suasana sekolah. Ini terkait dengan pilihan kata yang tidak tepat. Hal tersebut dapat dilihat pada kalimat Suasana sekolahku ini sangat sejuk dan enak untuk dipandang. Penggunaan kata enak kurang tepat untuk mendeskripsikan keindahan yang menggunakan alat indera penglihatan. Selain itu, penggunaan kata dimana pada contoh di atas juga merupakan bentuk kesalahan karena kalimat tersebut tidak menyatakan sebuah bentuk pertanyaan. Adapun penggunaan bentuk ulang pohong-pohongjuga tidak benar karena terdapat tambahan $g$ bentuk baku dari kata ulang tersebut adalah pohon-pohon.

\section{METODE PENELITIAN}

Jenis Penelitian dan Pendekatan

Berdasarkan jenisnya, penelitian ini adalah penelitian deskriptif kualitatif. Penelitian deskriptif digunakan untuk mendeskripsikan fakta-fakta kebahasaan berupa penggunaan ejaan dan pilihan kata karangan deskripsi siswa kelas VII SMP N 18 Lau. Pada penelitian ini digunakan pendekatan eksperimen yaitu pendekatan yang berupaya melihat pengaruh variable tertentu terhadap variabel yang lain.

\section{Sumber Data}

Sumber data dalam penelitian ini ialah karangan deskripsi siswa kelas VII SMP Negeri 18 Lau.

\section{Populasi dan Sampel}

Populasi dalam penelitian ini adalah keseluruhan karangan deskripsi siswa kelas VII SMP Negeri 18 Lau berjumlah40 karangan yang diperoleh dari empat kelas yang terbagi atas kelas kontrol dan kelas eksperimen. Sampel diperoleh dari kelompok eksperimen dan kelompok kontrol.

\section{Teknik Pengumpulan Data}

Pengumpulan data dilakukan dengan metode simak dengan teknik catat. Metode simak digunakan dengan mencermati dan memahami kemampuan 


\section{0 | JURNAL ILMU BUDA YA}

menulis karangan deskripsi serta mencermati kalimat-kalimat dalam karangan deskripsi meliputi penggunaan ejaan dan pilihan katanya. Selanjutnya, teknik catat sebagai lanjutan dari metode simak digunakan untuk mencatat data yang telah diperoleh. Data tersebut dicatat pada kartu data yang telah disiapkan untuk dianalisis lebih dalam. Adapun langkahlangkah pengumpulan data dilakukan sebagai berikut:

1) Membaca dengan cermat teks karangan deskripsiuntuk mengetahui penggunaan ejaan, kemampuan memahami dan mengembangkan gagasan, serta kohesi dan koherensi.

2) Menandai kalimat yang menunjukkan kelainan dalam penggunaan ejaan dengan menggunakan pensil.

3) Mencatat kalimat yang telah ditandai tersebut ke dalam kartu data.

4) Mengklasifikasikan data yang telah ditemukan.

\section{Teknik Analisis Data}

Data yang diperoleh melalui teknik catat selanjutnya dianalisis dengan menggunakan metode deskriptif. Metode deskriptif yakni melukiskan dan menggambarkan apa adanya data yang diperoleh dari penelitian. Analisis data dalam penelitian ini dimulai dengan cara pengkajian setiap karangan deskripsi. Data yang telah teridentifikasi dengan cara digaris bawahi atau diwarnai dengan stabilo, selanjutnya dicatat kemudian diklasifikasikan berdasarkan bagian penggunaannya meliputi penggunaan huruf, penggunaan kata dan penggunaan tanda baca.

\section{PEMBAHASAN}

A. Analisis Kemampuan Menulis Karangan Deskripsi Siswa Kelas VII di SMP Negeri 18 Lau melalui Media Gambar Seri

Kemampuan menulis karangan deskripsi siswa kelas VII di SMP Negeri 18 Lau melalui media gambar seri akan dianalisis berdasarkan unsur-unsur kebahasaannya meliputi ejaan, kemampuan pengembangan gagasan serta kohesi dan koherensinya. Pada penelitian ini, analisis kemampuan menulis karangan deskripsi siswa kelas VII di SMP Negeri 18 Lau akan diuraikan di bawah ini.

\section{Kelas Kontrol}

Pada kelas kontrol, dapat dianalisis karanag deskripsi siswa sebagai berikut.

\section{Bantimurung}

Saya bersama keluargaku pergi ke wisata Bantimurung yg terdapat di bantimurung setelah itu saya akan masuk ke pintu gerbang baru saya melihat patung kupukupu yg gagah besar dan saya melihat patung monyet yang besar disamping kanan kupu-kupu terdapat gunung dan di samping kiri kupu-kupu dapat berjalan di kanan monyet terdapat jalan setelah saya melewati gerbang.

dan saya masuk wisata alam bantimurung dan saya melihat membeli karcis setelah itu saya bersama keluarga melihat patung kupu-kupu yang kecil setelah itu saya saya pergi mengganti baju dan setelah itu saya dan keluargaku memesan rumah2 tikar yang seharga 30.000 sampai 45.000 ribu rupiah itu saya sudah saya pergi bermandi-mandi dan setelah itu saya sudah bermandi-mandi. dan pergi mengganti pakainyan dan saya tdk lupa membeli oleh-oleh kas bantimurung yg terdapat Sulawesi selatan saya membelli jangung bakar dan tdk lupa jangan membeli bingkai kupu-kupu.

Taman wisata bantimurung terdapat sul-sel yang banyak dikunjungi oleh masyarakat Indonesia.

Berdasarkan lima karangan yang merupakan hasil teks deskripsi yang diperoleh dari kelas kontrol, maka di bawah ini adalah analisis terhadap penggunaan bahasa karangan yang ditulis siswa kelas VII SMP 18 Lau tersebut.

1. Ejaan

Pada bagian ini, analisis terhadap penggunaan ejaan terdiri atas penulisan huruf, penulisan kata dan penggunaan tanda baca. Berikut ini akan diuraiakan satu per satu.

a) Penulisan Huruf 


\section{1 | JURNAL ILMU BUDAYA}

\author{
Penulisan huruf terdiri atas \\ beberapa, yaitu: \\ 1) Huruf Kapital \\ Dalam Pedoman Umum Ejaan
}

Bahasa Indonesia (PUEBI), terdapat sejumlah kaidah yang berhubungan dengan penulisan huruf kapital. Analisis kemampuan menulis karangan pada siswa kelas VII di SMP Negeri 18 Lau masih menunjukkan kelemahan dalam penulisan huruf kapital. Adapun kaidah penggunaan huruf kapital yang masih lemah pada karangan deskripsi siswa tersebut, akan diuraikan berikut ini.

(a) Huruf kapital dipakai sebagai huruf pertama awal kalimat.

Contoh (1)

adapun tembok dengan benteng kupu-kupu untuk memperingati hari kupu-kupu taman nasional banti murung dan banyak pondok pondok yang penuh orang-orang yg lagi senang memakan jagung bakar maupun berpoto poto

Contoh (2)

adapun air terjun yg sangat deras meliputi batu batuan dan banyak orang yg bergembira bermain air dan berenang dengan menaiki ban dalam mobil.

Contoh (3)

dalam rangka memperingati hari kupu-kupu taman nasional bantimurung dalam rangka itu banyak orang yang ingin menikmati semua fasilitas yang ada di taman nasional bantimurung.

Berdasarkan contoh (1) sampai dengan contoh (3) yang ditampilkan, terlihat bahwa kemampuan penulisan huruf kapital pada karangan deskripsi siswa kelas VII di SMP Negeri 18 Lau belum baik. Hal ini dapat dilihat pada penggunaan huruf kapital pada ketiga contoh di atas.

Berdasarkan Pedoman Umum Ejaan Bahasa Indonesia (PUEBI), terdapat sebuah kaidah penulisan huruf kapital yaitu huruf kapital dipakai sebagai huruf pertama awal kalimat. Berdasarkan kaidah tersebut, seyogyanya huruf pertama sebuah kalimat diawali dengan huruf kapital. Namun, kaidah tersebut tidak diberlakukan secara konsisten oleh siswa dalam memulai penulisan kata pada awal kalimat.

Pada contoh (1) dan (2), huruf pertama pada kata adapun seharusnya ditulis dengan menggunakan huruf kapital sehingga menandai dimulainya kalimat tersebut. sementara itu, pada contoh (3), kaidah penulisan huruf kapital pada huruf pertama awal kalimat juga belum diterapkan. Penggunaan kata dalam di awal kalimat, belum menggunakan huruf kapital.

(b) Huruf kapital dipakai sebagai huruf Contoh (4) pertama nama geografi.

Ketika saya sampai di bantimurung kami melihat patung kupu-kupu dan patung monyet kami menuju keparkiran dan wisata bantimurung yg sangat indah.

Contoh (5)

Bantimurung adalah wisata alam yg berada di kabupaten maros ketika kami mau masuk kami di sambut dengan kupu-kupu yang besar yg berarti mengucapkan selamat datang...

Contoh (6)

Pada saat masuk ke gerbang pertama bantimurung kami melihat patung kupu-kupu yang sangat besar yang terbuat dari besi cuaca hari itu sangat cerah.

Kaidah penulisan huruf kapital berikutnya yaitu huruf kapital dipakai sebagai huruf pertama nama geografi. Namun, berdasarkan contoh (4) sampai (6) tersebut, menunjukkan kemampuan penulisan huruf kapital siswa kelas VII 


\section{2 | JURNAL ILMU BUDAYA}

SMP Negeri 18 Lau pada karangan deskripsi belum benar.

$$
\text { Pada contoh (4) kata }
$$

Bantimurung menunjukkan nama geografi yakni nama salah satu kecamatan di Kabupaten Maros sekaligus menjadi nama sebuah wisata alam air terjun. Penulisan huruf pertama pada kata yang menunjukkan tempat tersebut seharusya ditulis secara kapital.

Adapun pada contoh (5), kaidah penulisan nama kabupaten juga belum sesuai dengan kaidah. Penulisan kata maros, seharusnya diawali dengan huruf kapital Maros yang menandai bahwa nama tersebut adalah sebuah nama yaitu nama kabupaten.

Pada contoh (6), penulisan kata bantimurung pada sejumlah kalimat kembali mengalami kekeliruan dan ini bersifat konsisten hampir pada semua siswa.

b) Penulisan Kata

1) Kata Berimbuhan

(a) Imbuhan (awalan, sisipan, akhiran, serta gabungan awalan dan akhiran)

Contoh (7)

Bantimurung merupakan tempat wisata alam yang sering di kunjungi oleh orang-orang.

Contoh (8)

Sesaat memasuki Bantimurung, pertama kali saya melihat patung kupukupu dengan patung monyet yang sudah menjadi ciri khasnya Bantimurung di sebelah kiri patungpatung tersebut terdapat pegunungan dan tumbuhan yang hijau sedang di sebelah kanan terdapat Taman kecil yang di penuhi bunga-bunga yang cantik dan segar untuk di pandang.

Contoh (9)

Di dalam bantimurung terdapat kolam dewasa dan kolam anak anak, dan terdapat air mancur dan seluncuran tinggi, dan terdapat penjual kerupuk, jagung, dan minuman. dan terdapat wc pria dan wc wanita dan di samping wc terdapat mushollah dan persewahan tikar untuk di tempati.

Berdasarkan ketiga contoh yang ditampilkan di atas, terlihat bahwa siswa belum memahami kaidah penulisan imbuhan. Kaidahnya adalah imbuhan (awalan, sisipan, akhiran, serta gabungan awalan dan akhiran) yang mengikuti bentuk atau kata dasar ditulis serangkai atau tanpa spasi.

Pada contoh (7) terlihat penggunaan bentuk awalan $d i$ - yang mengikuti bentuk asal kunjungi yang berasal dari kata dasar kunjung. Kata kunjung merupakan kata dalam Bahasa Indonesia yang berkelas kata verba. Dalam Kamus Besar Bahasa Indonesia (KBBI) Offline kata dasar kunjung mengandung makna datang untuk menjumpai; bertandang; berziarah . Berdasarkan makna kata dasar tersebut, kata bentukan dikunjungi merupakan bentuk pasif dari kata mengunjungi dan mengandung arti datang untuk dijumpai, ditandangi atau diziarahi. Melalui penjabaran makna kata tersebut, dapat dibuktikan bahwa diyang melekat pada kata kunjung adalah awalan (prefiks) bukan kata depan, sehigga seharusnya di- ditulis serangkai dengan kata yang diikutinya.

Sama halnya dengan contoh (8), terdapat dua kata yaitu di penuhidan di pandang yang keduaduanya ditulis secara terpisah dengan bentuk terikat $d i^{-}$. Dalam KBBI Offline kata dasar penuh menduduki kelas kata adjektiva yang mengandung makna sudah berisi seluruhnya; banyak memuat. Sementara itu, kata pandang menduduki kelas kata nomina dan mengandung makna penglihatan yang tetap dan agak lama. Berdasarkan makna kedua kata tersebut, keduanya tidak menunjukkan arah dan tempat, sehingga penulisan yang benar seharusnya ditulis serangkai dengan bentuk terikat $d i$ - karena $d i$ - pada 


\section{3 | JURNAL ILMU BUDA YA}

kedua kata tersebut menunjukkan prefiks bukan preposisi.

Adapun pada contoh (9) terdapat kata di tempati yang merupakan bentuk pasif dari kata menempati yang dalam KBBI offline mengandung makna diduduki; didiami. Kata ditempati merupakan bentuk verba pasif sehingga di- yang melekat didepan kata tempat tersebut adalah prefiks. Kaidah penulisan bentuk terikat atau prefiks $d i$ adalah dengan melekat pada bentuk dasar atau dengan kata lain ditulis tanpa spasi.

\section{Kelas Eksperimen}

Pada kelas eksperimen, juga akan dianalisis lima karangan siswa yang telah memperoleh perlakuan yakni pembelajaran dengan menggunakan media gambar seri.
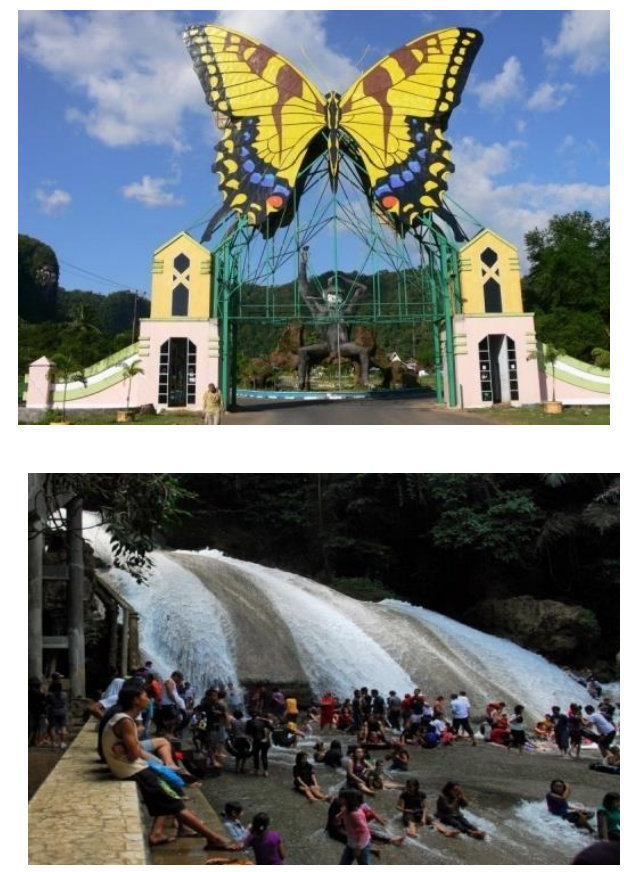

\section{BANTIMURUNG}

Pada saat masuk ke dalam pintu gerbang, di atas pintu gerbang terdapat patung kupu-kupu yang sangat indah. Di belakang patung kupu-kupu tersebut terdapat patung monyet yang sangat besar dan indah, dengan gaya memegang kepala dan pantatnya. Di sebelah kiri terdapat gunung dan pohon yang sangat lebat, dan di samping kanan terdapat waterpark bantimurung
Di dalam bantimurung terdapat kolam dewasa dan kolam anak anak, dan terdapat air mancur dan seluncuran tinggi. dan terdapat penjual kerupuk, jagung, dan minuman. dan terdapat wc pria dan wc wanita dan di samping wc terdapat mushollah dan persewahan tikar untuk di tempati.

Setelah itu terdapat pembelian tiket sebelum masuk ke dalam taman wisata alam Bantimurung, dan banyak penjual makanan, jagung bakar, manisan, dan penjual nasi kuning. dan terdapat patung kupu kupu yang sangat indah dan cantik. yang tertulis the kingdom of butterfly yang sangat indah.

Di dalam taman wisata alam bantimurung terdapat air terjun yang sangat tinggi dan indah dan mempunyai pemandangan yang sangat cantik dan

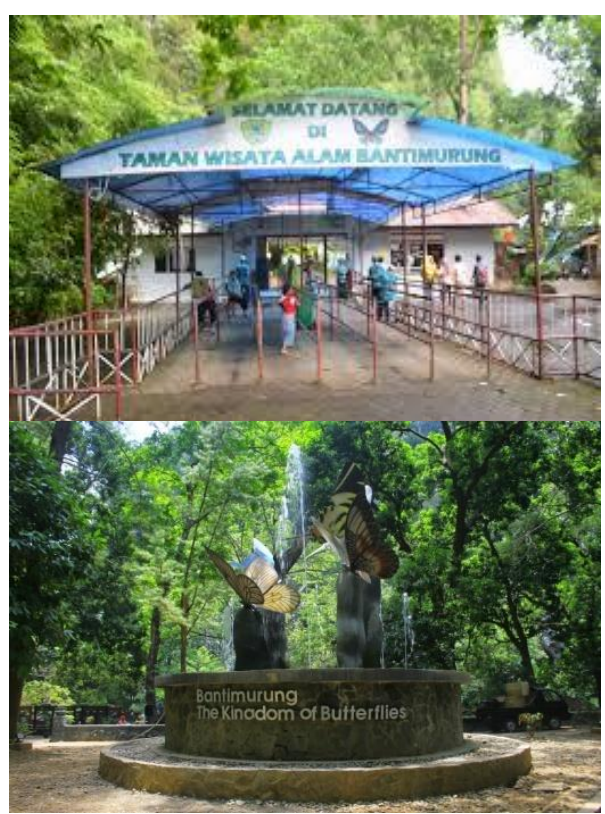

sangat dingin dan sejuk. Banyak orang yang bermandi-mandi di bawah air terjun yang sejuk itu dan disamping air terjun terdapat tangga seribu yang sangat tinggi. Di atas tangga seribu terdapat suara hewan lainnya. Di atas tangga seribu terdapat gua yang sangat gelap. Jika ingin memasuki gua mimpi itu harus menyewa senter.

Adapun analisis terhadap penggunaan bahasa, kesatuan gagasan serta kohesi dan koherensi karangan deskripsi siswa kelas VII SMP 18 Lau dapat diuraiakan sebagai berikut. 


\section{4 | JURNAL ILMU BUDAYA}

\section{Ejaan}

Pada bagian ini, analisis terhadap penggunaan ejaan terdiri atas penulisan huruf, penulisan kata dan penggunaan tanda baca. Berikut ini akan diuraiakan satu per satu.

a) Penulisan Huruf

Penulisan huruf terdiri atas beberapa, yaitu:

1) Huruf Kapital

Dalam Pedoman Umum Ejaan

Bahasa Indonesia (PUEBI), terdapat sejumlah kaidah yang berhubungan dengan penulisan huruf kapital. Analisis kemampuan menulis karangan pada siswa kelas VII di SMP Negeri 18 Lau dengan menggunakan media gambar seri menunjukkan hasil yang baik. Hal ini dapat dilihat dari kesesuaian kaidah dengan penerapannya.

Contoh (1)

Pada saat masuk ke dalam pintu gerbang, di atas pintu gerbang terdapat patung kupukupu yang sangat indah. Di belakang patung kupu-kupu tersebut terdapat patung monyet yang sangat besar dan indah, dengan gaya memegang kepala dan pantatnya. Di sebelah kiri terdapat gunung dan pohon yang sangat lebat, dan di samping kanan terdapat waterpark bantimurung

Contoh (2)

Pada hari itu saya dan keluarga berlibur ke wisata alam Bantimurung, di sana pada saat saat saya masuk ke gerbang pemandangan pertama yang saya lihat yaitu patung monyet dan kupu-kupu yang besar.

Contoh (3)

Pada suatu hari saat ke wisata alam Bantimurung yang pertama kita lihat adalah pagar dan di atas pagar itu terdapat gambar hewan yang berupa kupu-kupu yang berwarna biru hitam dan di samping kanan kirinya terdapat pepohonan.

Pada contoh 1 terlihat kaidah penggunaan huruf kapital pada awal kalimat telah diterapkan. Jadi, kata apapun itu jika berada pada awal kalimat ditulis dengan huruf kapital.
Adapun pada contoh (2) tampak kaidah penggunaan huruf kapital pada nama geografi juga telah diterapkan dengan baik. Kata Bantimurung selalku ditulis dengan $B$ huruf kapital pada awal kata.

2. Kemampuan Mengembangkan Gagasan

Media gambar seri memiliki
pengaruh yang cukup besar terhadap
kemampuan siswa dalam mengembangkan
gagasannya. Hal ini dapat diketahui dari
tulisan yang dihasilkan siswa.
Kendala-kendala yang Dihadapi Siswa
dalam Menyusun Karangan Deskripsi
Menggunakan Media Gambar Seri

Berdasarkan penelitian pada beberapa karangan deskripsi siswa kelas VII SMP Negeri 18 Lau tampak bahwa dalam menulis karangan deskripsi dengan menggunakan media gambar seri, masih ditemukan beberapa kendala yang cukup berarti yang seyogyanya hal tersebut dapat diminimalisir.

Berdasarakan beberapa indikator unsur-unsur kebahasaan yang diteliti dalam melihat kemampuan siswa, berikut ini akan dituliskan beberapa kendala yang terjadi baik dari sudut pandang guru maupun siswa.

1. Sudut Pandang Guru

Berdasarkan sudut pandang guru, tidak menutup kemungkinan kendala dalam proses pembelajaran itu bisa saja terjadi karena guru menjadi pihak yang berperan penting dalam proses pembelajaran di kelas. Hampir seluruh ilmu pengetahuan bersumber dari guru, yang selanjutnya berupaya ditransformasikan kepada siswa.

Guru sebagai pihak yang terlibat atau dengan kata lain pihak yang paling dekat dengan siswa sebisa mungkin menggunakan sejumlah media pembelajaran untuk mencapai hasil pembelajaran yang memuaskan. Realisasi penggunaan media gambar seri dalam menulis karangan deskripsi siswa kelas VII di SMP 18 Lau telah menunjukkan adanya hasil yang berbeda dengan siswa yang tidak diberi 
perlakuan atau siswa yang diajar dengan metode konvensional. Kendalakendala tersebut dapat diuraiakan sebagai berikut.

a) Sebagian guru masih menggunakan metode pembelajaran tradisional.

b) Terbatasnya kemampuan guru untuk menyediakan media gambar sesuai dengan konsep pembelajaran.

c) Guru belum mampu menggunakan media pembelajaran gambar seri secara kontinu.

2. Sudut Pandang Siswa

Dari sudut pandang siswa, dapat diketahui bahwa pemahaman awal tentang karangan deskripsi itu telah ada dalam pikiran siswa-siswa itu sendiri. Namun, kemampuan siswa dalam menggunakan ilmu-ilmu kebahasaan untuk mendeskripsikan secara konkret objek yang diberikan belum maksimal. Hal tersebut terjadi disebabkan oleh kendala berikut ini.
(a) Siswa belum menguasai kaidah ejaan dengan baik
(b) Siswa kurang serius dalam mengerjakan tugas
(c) Adanya pengaruh ragam bahasa
lokal

\section{KESIMPULAN}

Penelitian ini memberikan deskripsi yang jelas bahwa penggunaan media gambar sebagai media pembelajaran terbukti dapat meningkatkan keterampilan menulis karangan deskripsi peserta didik, dalam hal (1) kemampuan mengorganisasikan gagasan secara terpadu, (2) Pemilihan kata/ diksi secara tepat, (3) penggunaan kosakata secara bervariatif, (4) kohesi dan (koherensi) (5) teknik penulisan yang sesuai dengan ejaan Bahasa Indonesia yang disempurnakan (EYD) sehingga penelitian ini dapat digunakan suatu pertimbangan bagi guru yang ingin menerapkan gambar dalam pembelajaran sebagai salah satu media pembelajaran yang inovatif. Pemanfaatan media gambar seri dapat merangsang dan memotivasi peserta didik agar terlibat aktif selama proses belajar-mengajar serta mampu menghasilkan tulisan yang baik melalui pembelajaran menulis karangan deskripsi .

Adapun kendala-kendala dalam penggunaan media gambar tersebut dalam pembelajaran, dari sudut pandang guru yakni (a) sebagian guru masih menggunakan metode pembelajaran tradisional, (b) terbatasnya kemampuan guru untuk menyediakan media gambar sesuai dengan konsep pembelajaran dan (c) guru belum mampu menggunakan media pembelajaran gambar seri secara kontinu. Adapun dari sudut pandang siswa (a) Siswa belum menguasai kaidah ejaan dengan baik, (b) siswa kurang serius dalam mengerjakan tugas dan (c) adanya pengaruh ragam bahasa lokal.

\section{DAFTAR PUSTAKA}

Azhar, Arsyad. (2002). Media Pembelajaran. Jakarta: PT Raja Grafindo Persada.

Djago Tarigan, dan H.G.Tarigan.(1997). $\begin{array}{ll}\text { Teknik } & \text { Pengajaran } \\ \text { Keterampilan } & \text { Berbahasa. }\end{array}$ Bandung: Angkasa.

Kartono, St. (2009). Menulis Tanpa Rasa Takut. Yogyakarta: Kanisius.

Keraf, Gorys. (1994). Argumentasi dan Narasi. Jakarta: Gramedia.

Saddiah. 2015. Upaya Meningkatkan Keterampilan Menulis Karangan Narasi melalui Media Gambar Seri pada Siswa Kelas V Madrasah Ibtidaiyah Sis Aljufri Tatura Palu. e-Jurnal Bahasantodea, Volume 3 Nomor 1.

Semi, Atar M. 2007. Menulis Efektif. Padang: Angkasa.

Subana, \& Sunarti. (2000). Strategi Belajar Mengajar Bahasa Indonesia. Bandung: Pustaka Setia. 
Tarigan, H. G. (2008). Menulis Sebagai Suatu Keterampilan Berbahasa. rev. ed. Bandung: Angkasa. (1985). Pengajaran Gaya

Bahasa. Bandung: Angkasa.
Wina Sanjaya. (2011).Penelitian Tindakan Kelas. Jakarta: Prenada Media Group.

Yunus, Muhammad dan Suparno. 2007. Keterampilan Dasar Menulis. Jakarta: Universitas Terbuka. 